KHAZANAH MULTIDISIPLIN

VOL 1 NO 12020

https://journal.uinsgd.ac.id/index.php/km

\title{
ANALISIS KELEMBAGAAN DESA DALAM SISTEM KETATANEGARAAN REPUBLIK INDONESIA
}

\author{
Ahmad Maula Hadi \\ Program Pascasarjana Ilmu Hukum Universitas Islam Negeri Sunan \\ Gunung Djati Bandung \\ Email : ahmadmaulahadi26@gmail.com
}

\begin{abstract}
ABSTRAK
Era reformasi menuntut lembaga-lembaga dalam struktur ketatanegaraan di Indonesia untuk terus berkembang dengan harapan kebutuhan masyarakat terhadap demokrasi terpenuhi. Tidak sedikit lembaga yang bermunculan pasca reformasi, baik di tingkat pusat maupun di tingkat daerah, namun tidak sedikit pula lembaga-lembaga yang bermunculan ini menimbulkan banyak persoalan baru. Sebagaimana lembaga pemerintah Desa yang secara kelembagaan semakin dikuatkan dengan adanya Undang-Undang Nomor 6 Tahun 2014 Tentang Desa. Semangat penguatan Desa secara kelembagaan diharapkan dapat muncul kemandirian Desa dalam menyejahterakan masyarakatnya. Akan tetapi, secara struktur kelembagaan, penguatan lembaga pemerintah Desa, baik secara kedudukan, maupun kewenangannya, justru memunculkan ketidakjelasan.

Penelitian ini bertujuan untuk mengetahui dan memahami gambaran Desa secara struktur kelembagaan berdasarkan Undang-Undang Nomor 6 Tahun 2014 Tentang Desa dengan fokus penelitian kepada status hukum, fungsi hukum, kedudukan hukum, dan peranan lembaga tersebut dalam konstruksi hukum tata negara.Hasil yang diperoleh dari makalah ini adalah 1)/ Desa yang merupakan lingkup organisasi atau susunan pemerintahan terkecil dan lebih dekat dengan masyarakat, mempunyai peran penting dalam menjalankan otonomi yang diamanatkan oleh konstitusi sebagai jalan menuju rakyat yang sejahtera. Penting juga karena desa merupakan satuan terkecil dari bangsa ini yang menunjukkan keragaman Indonesia. Selama ini terbukti keragaman tersebut telah menjadi kekuatan penyokong bagi tegak dan eksisnya bangsa. Sehingga penguatan Desa secara status dan kedudukannya tidak dapat ditawar lagi. 2) Penguatan lembaga pemerintah Desa menimbulkan dampak yang tidak sedikit. Apabila dilihat dari penguatan kewenangannya, maka potensi menciptakan Desa yang otonom tidak dapat terhindarkan. Akan tetapi, potensi ke arah otonomi Desa tidak akan berjalan apabila pemerintah Desa dan masyarakatnya tidak menunjukkan kemandirian.
\end{abstract}

Kata Kunci: Lembaga Daerah, Desa, dan Pemerintahan Desa.

\section{ABSTRACT}

The reform era demands that institutions in the constitutional structure in Indonesia continue to develop in the hope that people's needs for democracy are met. Not a few institutions have sprung up after the reformation, both at the central and regional levels, but many of these institutions have sprung up causing many new problems. As a Village government institution which is institutionally strengthened by the existence of Law Number 6 of 2014 concerning Villages. The spirit of strengthening the village as an institution is expected to emerge village independence in the welfare of its people. However, in terms of institutional structure, strengthening Village government institutions, both in terms of position and authority, actually creates confusion.

This study aims to identify and understand the description of the village as an institutional structure based on Law Number 6 of 2014 concerning Villages with a research focus on legal status, legal function, legal position, and the role of the institution in the construction of constitutional law. The results obtained from this paper this is 1) / Village which is the scope of the smallest organization or structure of government and closer to the community, has an important role in carrying out the autonomy mandated 


\section{KHAZANAH MULTIDISIPLIN}

VOL 1 NO 12020

https://journal.uinsgd.ac.id/index.php/km

by the constitution as a path to prosperous people. It is also important because the village is the smallest unit of this nation which shows the diversity of Indonesia. So far, it has been proven that this diversity has become a supporting force for the upright and existence of the nation. So that the strengthening of the Village in terms of status and position cannot be negotiated. 2) Strengthening Village government institutions has had a significant impact. When viewed from the strengthening of its authority, the potential to create an autonomous village is inevitable. However, the potential for Village autonomy will not work if the Village government and its people do not show independence.

Keywords: Regional, Village, and Village Government Institutions.

\section{PENDAHULUAN}

Seiring dengan berkembangnya kesadaran demokrasi dan kenegaraan Indonesia pasca reformasi, UUD 1945 sebagai konstitusi dasar negara kita mengalami perubahan yang signifikan. Akibatnya, sistem ketatanegaraan kitapun mengalami perkembangan yang radikal. Disisi lain, perkembangan masyarakat, baik secara ekonomi, politik, dan sosial budaya, serta pengaruh globalisme, dan lokalisme, menghendaki struktur organisasi negara yang lebih responsif terhadap tuntutan mereka serta lebih efektif dan efisien dalam melakukan pelayanan publik dan mencapai tujuan penyelenggaraan pemerintah. Perkembangan tersebut berpengaruh terhadap struktur organisasi negara, termasuk bentuk-bentuk dan fungsi-fungsi lembaga negara.

Berkembangnya demikian banyak lembaga-lembaga yang bersifat independen mencerminkan adanya kebutuhan untuk mendekonsentrasikan kekuasaan dari tangan birokrasi ataupun organorgan konvensional pemerintahan tempat kekuasaan selama masa-masa sebelumnya terkonsentrasi. Sebagai akibat tuntutan perkembangan yang semakin kompleks dan rumit, organisasi-organisasi kekuasaan yang birokratis, sentralistis dan terkonsentrasi tidak dapat diandalkan lagi. Oleh karena itu, pada waktu yang hampir bersamaan, muncul gelombang deregulasi, debirokratisasi, privatisasi, desentralisasi, dan dekonsentrasi. ${ }^{1}$

\footnotetext{
${ }^{1}$ Jimly Asshidiqqie, Perkembangan dan Konsolidasi Lembaga Negara Pasca Reformasi, Jakarta: Sinar Grafika, 2012, 20.
} 


\section{KHAZANAH MULTIDISIPLIN}

VOL 1 NO 12020

https://journal.uinsgd.ac.id/index.php/km

Gelombang-gelombang demikian tidak hanya terjadi pada tiga poros kekuasaan di tingkat pusat. Di tingkat daerah, bahkan sampai lembaga pemerintah desapun sudah mengalami perubahan-perubahan. Khususnya lembaga pemerintah desa, hal tersebut didorong oleh keterbatasan kemampuan pemerintah Desa dalam menjalankan fungsi dan peranannya menyebabkan pertumbuhan dan perubahan sosial di Desa berjalan lambat. Masyarakat Desa cenderung pasif dalam melakukan perubahan sosial dan ekonomi. Situasi ini menyebabkan masyarakat Desa semakin tergantung pada pihak luar Desa. Pertimbangan kesejarahan dan adaptasi serta antisipasi terhadap berbagai tuntutan perkembangan, termasuk dalam penyelenggaraan pemerintahan, menjadi dasar pengembangan Desa ke depan. Sejalan dengan hal tersebut, pemerintah telah memberikan landasan sebagai arah pengembangan Desa di masa yang akan datang. ${ }^{2}$

Oleh karena itu, secara regulasi, Desa memiliki Undang-Undang sendiri, yaitu Undang-Undang Nomor 6 Tahun 2014 Tentang Desa. Penguatan secara kelembagaan dan regulasi ini dinilai baik bagi kesejahteraan masyarakatnya. Akan tetapi, dalam kajian hukum lembaga negara, kedudukan sebuah lembaga negara dapat dipengaruhi oleh kewenangannya, produk hukum yang melahirkan, cara penulisannya, dan wilayah hukumnya. Apabila hal tersebut tidak dirumuskan secara baik dan benar, maka yang terjadi adalah munculnya berbagai persoalan baru. Maka dari itu, melalui tulisan ini, Penulis akan mencoba untuk mengkaji lembaga pemerintah desa, dimulai dari status hukumnya, fungsi hukumnya, kedudukan hukumnya, sampai peranan lembaga tersebut dalam konstruksi hukum tata negara.

\section{METODE PENELITIAN}

Dalam hal metode, makalah ini menggunakan teknik pengambilan data yang berdasarkan pada metode kepustakaan (library research). Metode

\footnotetext{
${ }^{2}$ M. Mas'ud Said, Arah Baru Otonomi Daerah di Indonesia, Malang: UMM Press, 2005, 54.
} 
KHAZANAH MULTIDISIPLIN

VOL 1 NO 12020

https://journal.uinsgd.ac.id/index.php/km

kepustakaan (library research) itu sendiri adalah pengambilan data dengan cara menelaah beberapa literatur serta bacaan-bacaan lain dan bahan-bahan hukum yang masih relevan serta berhubungan dengan obyek penelitian. 3

\section{HASIL DAN PEMBAHASAN}

\section{Status dan Kedudukan Hukum}

Lembaga negara dari segi hierarkinya dapat dibedakan menjadi tiga lapis, yaitu:

a) Organ lapis pertama yang disebut sebagai lembaga tinggi negara;

b) Organ lapis kedua yang disebut sebagai lembaga negara; dan

c) Organ lapis ketiga yang disebut sebagai lembaga daerah. 4

Lembaga daerah menurut Jimly Asshidiqqie mencakup:5

a) Daerah Provinsi;

b) Daerah Kabupaten;

c) Daerah Kota;

d) Perangkat Daerah;

e) Desa dan Pemerintahan Desa.

Dalam tulisan ini, pembahasan tidak akan dilakukan secara sistematis dari lembaga daerah yang paling tinggi, melainkan langsung mengerucut kepada Desa dan Pemerintahan Desa.

Pengaturan tentang Desa telah mengalami perubahan beberapa kali sejak Zaman Kolonial yakni Regeeringsreglement yang merupakan cikal bakal pemerintahan desa. Setidaknya ada beberapa aturan perundangundangan yang muncul sejak tahun 1945, diantaranya Undang-Undang No. 1 Tahun 1945 tentang Kedudukan Desa dan Kekuasaan Komite Nasional Daerah, Ketetapan MPRS No. II/MPRS/1960 tentang Garis-Garis Besar Pola Pembangunan Semesta Berencana Tahapan Pertama 1961-1969,

\footnotetext{
${ }^{3}$ Ronni Hanitijo Soemitro, Metodologi Penelitian Hukum, Jakarta: Ghalia Indonesia, 1985, 12.

${ }^{4}$ Jimly Asshiddiqie, Menuju Negara Hukum yang Demokratis, Jakarta: Bhuana Ilmu Populer, 2009, 467.

${ }^{5}$ Jimly Asshidiqqie, Perkembangan dan Konsolidasi Lembaga Negara Pasca Reformasi, 236.
} 


\section{KHAZANAH MULTIDISIPLIN}

VOL 1 NO 12020

https://journal.uinsgd.ac.id/index.php/km

Undang-Undang No. 5 Tahun 1979 tentang Pemerintahan Desa, PP No. 76 Tahun 2001 tentang Pedoman Umum Pengaturan mengenai Desa, PP No. 72 Tahun 2005 tentang Desa, Undang-Undang Nomor 6 Tahun 2014 tentang Desa.

Perubahan fundamental pengaturan terkait pemerintahan desa ini tentunya memberikan implikasi dalam perkembangan dan dinamika desa terutama dalam hal tata kelola pemerintahan desa, mulai dari perubahan bentuk desa menjadi kelurahan sampai persoalan aturan mengenai hak asal usul dan kewenangan desa yang bisa saja berbenturan dengan Peraturan Daerah yang telah ada sebelumnya. Perkembangan pengaturan desa ini juga membawa implikasi pada tingkat kesiapan daerah dalam pembangunan desa dan peningkatan peran serta masyarakat dalam rangka tata kelola pemerintahan di desa.

Sebagai ujung tombak pembangunan masyarakat, Desa sebagaimana disebutkan dalam Undang-Undang Nomor 23 Tahun 2014 Tentang Pemerintahan Daerah merupakan kesatuan masyarakat hukum yang memiliki batas wilayah, yang berwenang untuk mengatur dan mengurus urusan pemerintahan, kepentingan masyarakat setempat, berdasarkan prakarsa masyarakat, hak asal-usul dan/atau hak tradisional yang diakui dan dihormati dalam sistem pemerintahan Negara Kesatuan Republik Indonesia.

Desa yang merupakan lingkup organisasi atau susunan pemerintahan terkecil dan lebih dekat dengan masyarakat, mempunyai peran penting dalam menjalankan otonomi yang diamanatkan oleh konstitusi sebagai jalan menuju rakyat yang sejahtera. Dalam Pasal 1 Angka (1) UndangUndang Nomor 6 Tahun 2014 Tentang Desa disebutkan bahwa:

"Desa merupakan desa dan desa adat atau yang disebut dengan nama lain, selanjutnya disebut desa, adalah kesatuan hukum memiliki batas wilayah yang berwenang untuk mengatur dan mengurus urusan pemerintahan, kepentingan masyarakat setempat berdasarkan prakarsa 


\section{KHAZANAH MULTIDISIPLIN}

VOL 1 NO 12020

https://journal.uinsgd.ac.id/index.php/km

masyarakat, hak asal-usul, dan/atau hak tradisional yang diakui dan dihormati dalam sistem Negara Kesatuan Republik Indonesia.”

Dari definisi tersebut, sebetulnya desa merupakan bagian penting bagi keberadaan bangsa Indonesia. Penting karena desa merupakan satuan terkecil dari bangsa ini yang menunjukkan keragaman Indonesia. Selama ini terbukti keragaman tersebut telah menjadi kekuatan penyokong bagi tegak dan eksisnya bangsa. Dengan demikian penguatan desa menjadi hal yang tak bisa ditawar dan tak bisa dipisahkan dari pembangunan bangsa ini secara menyeluruh. Oleh karena itu, keberadaan desa perlu diberdayakan dan dilindungi, terutama dalam pelaksanaan kewenangannya.

Akan tetapi, dalam kajian hukum lembaga negara, lembaga atau organ yang dibentuk oleh Undang-Undang memiliki tingkatan yang lebih tinggi dibandingkan dengan lembaga yang dibentuk dibawah Undang-Undang, begitu juga dengan functie atau kewenangannya. 6 Terlebih lagi, Desa dibentuk oleh Undang-Undang yang secara khusus mengatur tentang Desa, yaitu Undang-Undang Nomor 6 Tahun 2014 Tentang Desa. Padahal Desa merupakan satuan pemerintah terkecil dalam struktur pemerintahan di Indonesia. Berbeda dengan kelurahan yang memiliki derajat setingkat dengan Desa tetapi tidak dibentuk dengan Undang-Undang khusus yang mengatur tentang kelurahan.

Menurut Jimly Asshiddiqie,7 lembaga-lembaga daerah itu dapat dibedakan menurut peraturan yang membentuknya, yaitu:

1) Lembaga Daerah yang dibentuk berdasarkan Undang-Undang Dasar, Undang-Undang, Peraturan Pemerintah, atau Peraturan Presiden yang pengangkatan anggotanya dilakukan dengan Keputusan Presiden;

2) Lembaga Daerah yang dibentuk berdasarkan peraturan tingkat pusat atau Peraturan Daerah Provinsi, dan pengangkatan anggotanya ditetapkan dengan Keputusan Presiden atau pejabat pusat;

\footnotetext{
${ }^{6}$ Ibid., 237.

${ }^{7}$ Ibid., 46.
} 


\section{KHAZANAH MULTIDISIPLIN}

VOL 1 NO 12020

https://journal.uinsgd.ac.id/index.php/km

3) Lembaga Daerah yang kewenangannya diatur dalam Perda Provinsi dan pengangkatan anggotanya dilakukan dengan Keputusan Gubernur;

4) Lembaga daerah yang dibentuk berdasarkan Peraturan Gubernur yang pengangkatan anggotanya ditetapkan dengan Keputusan Gubernur;

5) Lembaga Daerah yang dibentuk berdasarkan Peraturan Gubernur yang pengangkatan anggotanya ditetapkan dengan Keputusan Bupati/Walikota;

6) Lembaga Daerah yang dibentuk berdasarkan Perda Kabupaten/Kota yang pengangkatan anggotanya ditetapkan dengan Keputusan Bupati/Walikota;

7) Lembaga yang dibentuk berdasarkan Peraturan Bupati/Walikota yang pengangkatan anggotanya ditetapkan dengan Keputusan Bupati/Walikota.

Apabila dilihat dari kedudukannya, Desa merupakan salah satu wilayah penunjang bagi terbentuknya organ pemerintahan yang lebih tinggi, yaitu Kecamatan. Dalam Pasal 222 Ayat (2) Undang-Undang Nomor 23 Tahun 2014 Tentang Pemerintahan Daerah menyebutkan persyaratan dasar adanya sebuah Kecamatan meliputi:

a) Jumlah penduduk minimal;

b) Luas wilayah minimal;

c) Usia minimal Kecamatan; dan

d) Jumlah Desa/kelurahan yang menjadi cakupan.

Syarat tersebut mencerminkan bahwa Desa memiliki kedudukan yang sederajat dengan kelurahan dan posisinya berada dibawah Kecamatan secara kewilayahan. Persamaan yang dapat diambil antara Kecamatan, Kelurahan, dan Desa adalah merupakan organ pemerintah yang sama-sama memiliki wilayah secara geografis, dan wilayah secara kependudukan. Sehingga dalam hal ini, menjadi patut untuk diperbandingkan. Karena terjadi ketidakjelasan diantara struktur ketiga organ tadi.

Dalam bahasa hukum, lembaga negara yang huruf L dan N-nya ditulis dengan huruf besar memiliki kedudukan yang lebih tinggi dan kewenangan 


\section{KHAZANAH MULTIDISIPLIN}

VOL 1 NO 12020

https://journal.uinsgd.ac.id/index.php/km

yang lebih besar dibandingkan dengan lembaga negara yang huruf L dan Nnya ditulis dengan huruf kecil. Lembaga pemerintah Desa dalam beberapa pasal dalam Undang-Undang Nomor 23 Tahun 2014 Tentang Pemerintahan Daerah kerap kali ditulis dengan huruf kapital, yaitu Desa. Berbeda dengan kelurahan, ditulis dengan huruf kecil. Secara kedudukan antara Desa dengan kelurahan memiliki tingkatan yang sama tetapi memiliki perbedaan dalam penulisan. Dengan demikian, jika dibandingkan, maka Desa memiliki kedudukan dan kewenangan yang lebih besar daripada kelurahan.

\section{Fungsi dan Peranan Lembaga Pemerintah Desa}

Di dalam ilmu hukum, dikenal adanya teori fungsi dan teori organ. Dalam teori organ, negara dipandang sebagai suatu organisme. Lembagalembaga negara yang ada dalam suatu negara dikenal dengan alat perlengkapan negara (Die Staatsorgane). Alat perlengkapan negara dibentuk untuk menjalankan fungsi-fungsi negara. Pelaksanaan fungsifungsi, seperti wetgeving (legislatif), uitvoering (eksekutif), dan rechtspraak (yudikatif), menentukan persyaratan yang berbeda-beda kepada organ-organ (badan-badan atau lembaga-lembaga) tersebut, sehubungan dengan kehidupan masyarakat yang intern dan ekstern. ${ }^{8}$

Menurut Hans Kelsen, whoever fulfills a function determined by the legal order is an organ. 9 Siapa saja yang menjalankan suatu fungsi yang ditentukan oleh suatu tata hukum (legal order) adalah suatu organ. Jimly Asshiddiqie membedakan hal tersebut, walau diakui bahwa keduanya merupakan unsur pokok yang saling berkaitan. Organ adalah bentuk atau wadahnya, sedangkan functie adalah isinya. Organ adalah status bentuknya (Inggris: form, Jerman: vorm), sedangkan functie adalah gerakan wadah

\footnotetext{
${ }^{8}$ R. Kranenburg dalam A. Hamid S. Attamimi, Peranan Keputusan Presiden Republik Indonesia dalam Penyelenggaraan Pemerintahan Negara-Suatu Studi Analisis Mengenai Keputusan Presiden yang Berfungsi Pengaturan dalam Kurun Waktu Pelita I-Pelita V. (Disertasi Doktor, Universitas Indonesia, 1990), 99 dan 152.

${ }^{9}$ Hans Kelsen, General Theory of Law and State, New York: Russel\&Russel, 1961, 192.
} 


\section{KHAZANAH MULTIDISIPLIN}

VOL 1 NO 12020

https://journal.uinsgd.ac.id/index.php/km

itu sesuai maksud pembentukannya. ${ }^{10}$ Fungsi, menurut C.S.T Kansil dan Christine S.T. Kansil, ialah suatu lingkungan kerja dalam hubungan dengan keseluruhannya dan tidak terlepas satu sama lain selaku bagian-bagian untuk mencapai tujuan. Dengan demikian, fungsi menentukan kedudukan suatu badan. Satu fungsi dapat dipegang oleh satu badan atau lebih dan sebaliknya, beberapa fungsi dapat dipegang oleh satu badan. ${ }^{11}$

Bagir Manan mengategorikan 3 (tiga) jenis lembaga negara yang dilihat berdasarkan fungsinya, yakni: ${ }^{12}$

a) Lembaga Negara yang menjalankan fungsi negara secara langsung atau bertindak untuk dan atas nama negara, seperti Lembaga Kepresidenan, DPR, dan Lembaga Kekuasaan Kehakiman. Lembagalembaga yang menjalankan fungsi ini disebut alat kelengkapan negara.

b) Lembaga Negara yang menjalankan fungsi administrasi negara dan tidak bertindak untuk dan atas nama negara. Artinya, lembaga ini hanya menjalankan tugas administratif yang tidak bersifat ketatanegaraan. Lembaga yang menjalankan fungsi ini disebut sebagai lembaga administratif.

c) Lembaga Negara penunjang atau badan penunjang yang berfungsi untuk menunjang fungsi alat kelengkapan negara. Lembaga ini disebut sebagai auxiliary organ/agency.

Sehubungan dengan ketiga hal diatas, maka dari segi fungsinya, ada lembaga yang bersifat utama atau primer, dan adapula yang bersifat sekunder atau penunjang (auxiliary).13 Berdasarkan Pasal 18 UndangUndang Nomor 6 Tahun 2014 Tentang Desa, lembaga pemerintahan Desa memiliki kewenangan yang meliputi bidang penyelenggaraan Pemerintahan Desa, pelaksanaan Pembangunan Desa, pembinaan kemasyarakatan Desa, dan pemberdayaan masyarakat Desa berdasarkan

\footnotetext{
10 Luthfi Widagdo Eddyono, Penyelesaian Sengketa Kewenangan Lembaga Negara Oleh Mahkamah Konstitusi, Jurnal Konstitusi, Volume 7, Nomor 3, Juni 2010, 13.

${ }^{11}$ Ibid.

12 Tri Jata Ayu Pramesti, "Perbedaan Lembaga Negara dan Alat Negara", Hukum Online.com, 18 September 2015.

13 Jimly Asshidiqqie, Perkembangan dan Konsolidasi Lembaga Negara Pasca Reformasi, 467.
} 


\section{KHAZANAH MULTIDISIPLIN}

VOL 1 NO 12020

https://journal.uinsgd.ac.id/index.php/km

prakarsa masyarakat, hak asal usul, dan adat istiadat Desa. Kemudian dalam Pasal 19, desapun memiliki kewenangan meliputi:

a) Kewenangan berdasarkan hak asal usul;

b) Kewenangan lokal berskala Desa;

c) Kewenangan yang ditugaskan oleh Pemerintah, Pemerintah Daerah Provinsi, atau Pemerintah Daerah Kabupaten/Kota; dan

d) Kewenangan lain yang ditugaskan oleh Pemerintah, Pemerintah Daerah Provinsi, atau Pemerintah Daerah Kabupaten/Kota sesuai dengan ketentuan perundangan-undangan.

Pasal 67 Undang-Undang Nomor 6 Tahun 2014 Tentang Desa menegaskan, Desa berhak mengatur dan mengurus kepentingan masyarakat berdasarkan hak asal usul, adat istiadat, dan nilai sosial budaya masyarakat Desa; menetapkan dan mengelola kelembagaan Desa; dan mendapatkan sumber pendapatan. Sementara masyarakat Desa berhak meminta dan mendapatkan informasi dari Pemerintah Desa serta mengawasi kegiatan penyelenggaraan Pemerintahan Desa, pelaksanaan Pembangunan Desa, pembinaan kemasyarakatan Desa, dan pemberdayaan masyarakat Desa; serta memperoleh pelayanan yang sama dan adil.

Dari aspek kewenangan, terdapat tambahan kewenangan Desa dalam Undang-Undang Nomor 6 Tahun 2014, selain kewenangan yang didasarkan pada hak asal usul sebagaimana diakui dan dihormati negara (azas rekognisi), yaitu bahwa setiap peraturan desa memiliki azas subsidiaritas. Azas ini termaktub dalam Pasal 3 huruf b Undang-Undang Nomor 6 Tahun 2014 Tentang Desa. Dalam penjelasannya, maksud dari azas ini adalah memberikan keleluasaan dalam penetapan kewenangan berskala lokal dan pengambilan keputusan secara lokal untuk kepentingan masyarakat Desa. Konsekuensi dari pertambahan kewenangan tersebut memungkinkan Desa dapat mengembangkan otonomi yang dimiliki bagi kepentingan masyarakat setempat. Implikasinya, Desa dapat menggunakan sumber keuangan yang berasal dari negara dan pemerintah daerah untuk mengembangkan semua kewenangan yang telah ada, yang baru muncul, 


\section{KHAZANAH MULTIDISIPLIN}

VOL 1 NO 12020

https://journal.uinsgd.ac.id/index.php/km

dan sejumlah kewenangan lain yang mungkin merupakan penugasan dari supradesa.

Kepala Desa bertugas menyelenggarakan Pemerintahan Desa, pembinaan kemasyarakatan Desa, dan pemberdayaan masyarakat Desa. (Pasal 26 Ayat (1) UU Desa). Kepala Desa memegang jabatan selama 6 (enam) tahun dan dapat menjabat paling banyak 3 (tiga) kali masa jabatan. Terkait postur organisasi pemerintahan Desa, batasan pemerintahan Desa terdiri dari kepala Desa dan perangkat Desa semata tanpa posisi BPD. Batasan tersebut berbeda dengan PP No.72/2005, dimana pemerintahan Desa terdiri dari Kepala Desa dan BPD. Pemisahan posisi Kepala Desa beserta perangkatnya dari BPD memungkinkan pemerintahan Desa lebih efektif dalam melaksanakan otonomi Desa selain kewajiban dari supradesa.

Pengalaman menunjukkan bahwa kolektivitas Kepala Desa dan BPD sebagai unsur penyelenggara pemerintahan Desa sulit dilaksanakan karena kedua lembaga tak selalu sejalan dalam penetapan dan pelaksanaan kebijakan. Terpisahnya posisi BPD memungkinkan pemerintah Desa dapat lebih leluasa mengatur dan mengurus rumah tangganya sendiri tanpa pengawasan ketat BPD. Bias dari kondisi semacam itu tak jarang membuat Desa kurang dinamis. Separasi semacam itu bertujuan untuk menciptakan pemerintahan Desa yang lebih modern, dimana secara politik terjadi diferensiasi antara desainer kebijakan (BPD) dan implementator kebijakan (Kepala Desa). BPD setidaknya mewakili masyarakat yang dipilih secara demokratis untuk membahas suatu kebijakan sebelum dilaksanakan oleh pemerintah Desa. Perencanaan Desa dapat dikembangkan sejalan dengan periodisasi kepemimpinan Kepala Desa. Artinya, perencanaan menengah Desa dapat berjalan selama 18 tahun bergantung pada elektabilitas Kepala Desa. Periodisasi yang relatif lebih lama dibanding Kepala Daerah yang hanya dua periode, Desa dengan sendirinya berpeluang meletakkan perencanaan secara berkelanjutan melalui prioritas yang disepakati bersama masyarakat setempat. 


\section{KHAZANAH MULTIDISIPLIN}

VOL 1 NO 12020

https://journal.uinsgd.ac.id/index.php/km

Kewenangan Desa yang luas ditunjang oleh sumber keuangan yang menjanjikan tampak seperti pisau belati bermata dua. Dalam konteks BPD misalnya, praktis BPD tak memiliki fungsi pengawasan terhadap akuntabilitas Kepala Desa. Kekhawatiran tersebut bukan tanpa alasan, sebab pertanggungjawaban akhir tahun anggaran dan akhir masa jabatan Kepala Desa disampaikan kepada Kepala Daerah, dan bukan kepada BPD. Tugas BPD selain berfungsi sebagai lembaga pemerintahan hanya melakukan pembahasan dan menerima laporan dari masyarakat, tanpa kewenangan yang bersifat punishment. Kondisi semacam itu dapat melemahkan BPD sekaligus pada saat yang sama menguatkan Kepala Desa (executive heavy). Harus diakui bahwa batasan tentang pemerintahan Desa di satu sisi memberi keleluasaan bagi pemerintah Desa dalam menjalankan program Desa, namun disisi lain cenderung mengurangi checks and balance system sehingga pemerintah Desa berpeluang absen dari pengawasan wakil masyarakat. Luasnya kewenangan pemerintah Desa tanpa pengawasan kuat BPD pada akhirnya membuka peluang korupsi di Desa disebabkan sumber daya aparatur yang minim, apalagi jika pemerintah lalai dalam melakukan pembinaan dan pengawasan sebagaimana amanat UU Desa.

Secara logis pengelolaan otonomi Desa yang menjanjikan semacam itu tanpa pembinaan lewat pendidikan dan pelatihan dalam pengelolaan keuangan Desa justru dapat mendorong Desa ke ruang tahanan kejaksaan. Peluang korupsi tidak saja terbuka lebar secara internal pemerintah Desa, demikian pula faktor eksternal berupa rent seeking pemerintah daerah. Di luar itu, potensi terjadinya korupsi secara sistemik dimungkinkan karena peluang seorang Kepala Desa dapat bertahan selama 3 periode sehingga dengan mudah dapat melanggengkan kekuasaan lewat penggunaan sumber keuangan dan kewenangan yang luas. Semakin rendah pendidikan masyarakat semakin rendah pula daya kritisnya. Keadaan demikian akan memudahkan pemerintah Desa melakukan berbagai modus yang menguntungkan diri dan keluarga dekatnya. Kecenderungan demikian 


\section{KHAZANAH MULTIDISIPLIN}

VOL 1 NO 12020

https://journal.uinsgd.ac.id/index.php/km

semakin sering terjadi pada sebagian besar Desa yang tak cukup memiliki integritas moral dan derajat pendidikan yang memadai. Dalam banyak kasus pemerintah Desa sering kali berselingkuh dengan pemerintah daerah untuk saling menutupi berbagai kelemahan pertanggungjawaban, sekaligus merawat hubungan patron client dengan sejumlah pejabat yang bertanggungjawab dalam distribusi alokasi dana Desa.

Secara historis bakat feodalisme pemerintah Desa adalah produk kolonial yang cenderung lebih berorientasi pada kepentingan majikan/tuannya daripada kepentingan masyarakat. Kondisi demikian sering kali menjebak pemerintah Desa lupa diri hingga terciptanya oligarki, nepotisme, bahkan otoritarianisme pemerintahan Desa. Terciptanya gejala demikian dimulai sejak era Raffles berkuasa (1811-1816), di mana sistem seleksi Kepala Desa tampak berjalan secara demokratis setelah melalui serangkaian manipulasi untuk kepentingan politik penjajah. Namun harus disadari bahwa pertumbuhan dan perkembangan demokrasi Desa di Indonesia menurut Hanif Nurcholis ${ }^{14}$ tidaklah sama sebagaimana di dunia Barat. Perbedaan pendidikan dan kedewasaan politik masyarakat mengakibatkan demokrasi di tingkat Desa hingga dua ratus tahun lamanya tidak menghasilkan demokrasi substansial, kecuali demokrasi prosedural. Inilah yang menjadi salah satu sebab mengapa Desa tak dapat tumbuh dan berkembang dengan sehat meskipun mekanisme demokrasinya bekerja mendahului demokrasi langsung dewasa ini.

Di sisi lain, dengan menguatnya kewenangan Desa dan meningkatnya sumber-sumber keuangan Desa dalam jangka panjang dapat mendorong peningkatan kuantitas Desa. Tingginya diskresi dalam penataan Desa dapat membuat sibuk pemerintah daerah dalam mengatur lalu lintas perubahan status. Dengan pertimbangan pragmatis akan datangnya subsidi Desa maka birahi memekarkan Desa kemungkinan dapat menjadi trend di masa mendatang. Realitas semacam ini cenderung melahirkan konflik horizontal

\footnotetext{
14 Hanif Nurcholis, Dua Ratus Tahun Praktek Demokrasi Desa, Potret Kegagalan Adopsi Demokrasi Barat, Jurnal Ilmu Pemerintahan, MIPI, Edisi 38, Jakarta, 2013, 68.
} 


\section{KHAZANAH MULTIDISIPLIN}

VOL 1 NO 12020

https://journal.uinsgd.ac.id/index.php/km

dan vertikal di tingkat Desa akibat lambatnya pembentukan Desa serta sejumlah ketidakpuasan akibat kompetisi yang ketat dalam pemilihan Kepala Desa. Apalagi transisi dari status Desa persiapan ke Desa definitif yang hanya membutuhkan usia 1-3 tahun, tentu saja bukan halangan berarti dalam memperbanyak Desa baru atas nama kehendak masyarakat setempat.

\section{SIMPULAN}

Berdasarkan uraian diatas, dapat disimpulkan bahwa Desa yang merupakan lingkup organisasi atau susunan pemerintahan terkecil dan lebih dekat dengan masyarakat mempunyai peran penting dalam menjalankan otonomi yang diamanatkan oleh konstitusi sebagai jalan menuju rakyat yang sejahtera. Penting juga karena desa merupakan satuan terkecil dari bangsa ini yang menunjukkan keragaman Indonesia. Selama ini terbukti keragaman tersebut telah menjadi kekuatan penyokong bagi tegak dan eksisnya bangsa. Sehingga penguatan Desa secara status dan kedudukannya tidak dapat ditawar lagi. Akan tetapi, menurut Penulis, penguatan lembaga merupakan hal yang diperbolehkan selama lembaga tersebut secara kedudukan tidak berbenturan dengan lembaga lain atau lembaga yang lebih tinggi kedudukannya yang dapat menimbulkan ketidakjelasan dalam struktur ketatanegaraan di Indonesia.

Disamping itu, penguatan lembaga pemerintah Desa menimbulkan dampak yang tidak sedikit. Apabila dilihat dari penguatan kewenangannya, maka potensi menciptakan Desa yang otonom tidak dapat terhindarkan. Akan tetapi, potensi ke arah otonomi Desa tidak akan berjalan apabila pemerintah Desa dan masyarakatnya tidak menunjukkan kemandirian. Dibutuhkan kedewasaan dan pengetahuan yang memadai dalam mengelola pemerintahan Desa yang sudah berkembang seperti sekarang ini, sebab penyerahan kewenangan secara penuh dapat menciptakan poros-poros kekuasaan baru yang berpotensi corrupt dan tidak terawasi sehingga mencederai prinsip berdemokrasi.

\section{DAFTAR PUSTAKA}


KHAZANAH MULTIDISIPLIN

VOL 1 NO 12020

https://journal.uinsgd.ac.id/index.php/km

\section{Sumber Buku:}

Hanif Nurcholis. Dua Ratus Tahun Praktek Demokrasi Desa, Potret Kegagalan Adopsi Demokrasi Barat. Jurnal Ilmu Pemerintahan. MIPI. Edisi 38. Jakarta, 2013.

Hans Kelsen. General Theory of Law and State. New York: Russel\&Russel, 1961.

Jimly Asshiddiqie. Menuju Negara Hukum yang Demokratis. Jakarta: Bhuana Ilmu Populer, 2009. . Perkembangan dan Konsolidasi Lembaga Negara Pasca

Reformasi. Jakarta: Sinar Grafika, 2012.

Luthfi Widagdo Eddyono. Penyelesaian Sengketa Kewenangan Lembaga Negara Oleh Mahkamah Konstitusi. Jurnal Konstitusi. Volume 7. Nomor 3. Juni 2010.

M. Mas'ud Said. Arah Baru Otonomi Daerah di Indonesia. Malang. UMM Press. 2005.

R. Kranenburg dalam A. Hamid S. Attamimi, Peranan Keputusan Presiden Republik Indonesia dalam Penyelenggaraan Pemerintahan Negara - Suatu Studi Analisis Mengenai Keputusan Presiden yang Berfungsi Pengaturan dalam Kurun Waktu Pelita I - Pelita V. Disertasi Doktor. Universitas Indonesia. 1990.

Ronni Hanitijo Soemitro. Metodologi Penelitian Hukum. Jakarta: Ghalia Indonesia, 1985.

\section{Sumber Peraturan Perundang-undangan:}

Undang-Undang Dasar Negara Republik Indonesia Tahun 1945;

Undang-Undang Nomor 6 Tahun 2014 tentang Desa;

Undang-Undang Nomor 23 Tahun 2014 tentang Pemerintahan Daerah.

\section{Sumber Internet:}

Tri Jata Ayu Pramesti. "Perbedaan Lembaga Negara dan Alat Negara”. Hukum Online.com. 18 September 2015. 